\title{
STRATEGI BAURAN PEMASARAN PADA PB. DUA PUTRA DI DESA AJUNG KECAMATAN KALISAT JEMBER
}

\author{
Annisa Sari Surya Hanif ${ }^{1}$, Joko Widodo ${ }^{1}$, Mukhamad Zulianto ${ }^{1}$ \\ ${ }^{1}$ Program Studi Pendidikan, Fakultas Keguruan dan Ilmu Pendidikan, Universitas Jember \\ E-mail: sariannisa4@gmail.com
}

\begin{abstract}
Abstrak
PB. Dua Putra Ajung Kalisat Jember merupakan perusahaan yang bergerak dalam bidang usaha penggilingan padi. . Tempat penelitian ditentukan dengan menggunakan metode purposive area yang dilaksanakan di PB. Dua Putra Kalisat Jember. Analisis data dalam penelitian ini terdiri dari reduksi data, penyajian data, serta penarikan kesimpulan. Berdasarkan hasil penelitian dapat diketahui bahwa PB. Dua Putra Kalisat Jember menerapkan strategi bauran pemasaran. Adapun strategi bauran pemasaran yang dilakukan oleh PB. Dua Putra Kalisat Jember adalah strategi produk, strategi harga, strategi promosi, dan strategi distribusi. Strategi produk dalam PB. Dua Putra yaitu menjual produknya berupa beras dengan berbagai merk dengan perbedaan kualitas yang ditawarkan. Strategi tempat yaitu pemilihan tempat usaha yang berada di lokasi yang strategis, aman, dan nyaman bagi konsumen, strategi harga merupakan penetapan harga dengan mempertimbangkan kualitas beras yang diterapkan PB. Dua Putra dan penyesuaian harga di pasar, strategi promosi awal dilakukan dengan melalui iklan, brosur, banner dan juga pamflet khususnya hingga saat ini yang bertujuan menarik keminatan konsumen untuk membeli produk tersebut, dan strategi distribusi dimana dalam pengiriman barang berusaha untuk selalu tepat waktu, terutama pada saat pengiriman barang ke luar pulau.
\end{abstract}

Kata Kunci: Strategi Pemasaran, Bauran Pemasaran, strategi produk, strategi harga, strategi promosi, dan strategi distribusi.

\section{PENDAHULUAN}

Perusahaan yang mampu bertahan adalah perusahaan yang mampu memenuhi tuntutan pangsa pasar berupa produk yang sesuai dengan keinginan konsumen, yaitu berharga jual murah tetapi tanpa adanya pengurangan kualitas produk serta pengiriman produk yang tepat waktu. Hal ini tidaklah mudah karena dalam proses produksi sering kali ditemui adanya kendala-kendala yang akan menghambat suatu proses produksi, sehingga harga produk akan mengalami kenaikan walaupun harga jual tidak dinaikkan. Pengiriman produk ke tangan konsumen juga akan terhambat dengan adanya kendala yang terjadi tersebut.

Kendala adalah aktivitas-aktivitas yang memperlambat total waktu produksi. Kendala-kendala dari perusahaan dapat berasal dari dalam perusahaan maupun dari luar perusahaan. Kendala-kendala tersebut dapat disebabkan oleh: 1) Sumber daya yang digunakan dalam proses produksi, misalnya, bahan baku (kualitas yang bervariasi dan volume), produktivitas tenaga kerja yang menurun, kapasitas mesin yang terbatas yang dapat dirasakan oleh perusahaan ketika

Kemampuan manajer dalam mengatur pendayagunaan sumber daya yang berkendala seoptimal mungkin. 3. Permintaan pasar yang diperhitungkan. Dimana apabila produk menghasilkan output lebih besar dari permintaan, pasar akan menimbulkan pengeluaran yang sia-sia.

Adanya kendala-kendala yang ditemui dalam perusahaan serta adanya tuntutan konsumen membuat persaingan menjadi lebih ketat. Agar dapat menghadapi para kompetitor, manajer perusahaan dituntut untuk dapat menyadari pentingnya strategi pemasaran secara efektif dan efisien yang sesuai dengan kondisi perusahaan. Efisiensi merupakan hal penting yang harus mendapat perhatian serta perlu peningkatan dalam pengelolaan sumber daya yang terbatas sehingga perusahaan dapat survive dan mencapai tujuan perusahaan secara maksimal.

Kendala-kendala yang terjadi dapat diatasi melalui suatu suatu strategi pemasaran yaitu bauran pemasaran (marketing mix) jika disesuaikan dengan kondisi perusahaan yang diteliti, dimana bauran pemasaranmerupakan suatu kumpulan dari variabel-variabel pemasaran (product, price, place, promotion). Marketing mix ini bisa digunakan oleh suatu badan usaha untuk mencapai tujuan pemasaran pada sasaran pasar yang tepat. Bauran pemasaran juga dimanfaatkan sebagai alat pemasaran suatu perusahaan untuk mencapai target pasar. Tak hanya itu, bauran pemasaran ini juga terbentuk dari himpunan variabel dan bisa digunakan maupun dikendalikan oleh suatu perusahaan. Dengan cara demikian perusahaan akan membidik konsumen dengan tepat. Saat ini banyak produk beras yang sudah menguasai pangsa pasar mulai dari dalam kota hingga luar pulau. Hal tersebut dapat dilihat dari lingkup pemasaran masing - masing produk beras yang sering kita temukan di toko kecil hingga supermarket. Produk beras yang ada pada kabupaten Jember sendiri terdiri dari 
bermacam - macam merk antara lain beras Cap Zebra, Beras Cap Macan, Beras Cap Dua Anak, dan sebagainya.

Produk beras yang sudah familiar di kalangan masyarakat terutama lingkup kabupaten Jember adalah

Beras Cap Dua Anak yang diproduksi oleh Pabrik Beras Dua Putra Kalisat Jember. Walaupun masyarakat banyak yang menggunakan produk beras dengan berbagai macam merk lainnya, namun beras dengan merk Cap Dua Putra ini sudah cukup lama terkenal di kalangan masyarakat luas dan lebih banyak dikonsumsi karena kualitas beras dengan standar yang baik.bSeiring dengan hal itu, maka masih sangat berpeluang bagi PB. Dua Putra Kalisat Jember untuk tetap berproduksi.

PB. Dua Putra merupakan salah satu pabrik beras yang sangat diminati produknya oleh masyarakat di desa Ajung Kecamatan Kalisat Kabupaten Jember. Desa Ajung ini merupakan pusat sentra pertanian yang masih bertahan dan berproduksi hingga saat ini. Beras Cap Dua Anak merupakan salah satu produk beras PB. Dua Putra yang berkualitas unggulan di kalangan masyarakat luas. Pabrik beras atau PB. Dua Putra mulai berdiri pada tahun 1980. Pada tahun itu hingga tahun 2017 PB. Dua Putra mengalami puncak kejayaannya dengan mencapai omset yang lumayan tinggi per bulannya dengan merk - merk unggulan yang dihasilkan.

Seiring dengan banyaknya para pesaing dan omset penjualan yang naik turun, maka PB. Dua Putra yang ada di Desa Ajung Kecamatan Kalisat ini harus mencari cara agar produk - produk mereka tetap laku dan tetap bertahan untuk kedepannya dan mampu bersaing dengan para kompetitornya. PB. Dua Putra Kalisat Jember ini harus memiliki strategi pemasaran yang tepat agar usaha kedepannya tetap bertahan dan berproduksi. Perusahaan memiliki kekuatan dan kelemahan dalam area bisnisnya. Tidak ada perusahaan yang sama kuatnya atau sama lemahnya dalam semua area bisnis. Kekuatan dan kelemahan internal, digabungkan dengan peluang serta ancaman dari eksternal dan pernyataan misi yang jelas, menjadi dasar untuk penetapan tujuan dan strategi.

Tujuan dan strategi ditetapkan dengan cara memanfaatkan kekuatan internal dan mengatasi kelemahan. Dengan adanya suatu penerapan strategi yang didalamnya terdiri dari elemen - elemen pemasaran yang meliputi product (produk), price (harga), promotion (promosi), dan place (distribusi). PB Dua Putra Kalisat Jember seharusnya memilih strategi pemasaran yang tepat dan lebih bias mengoptimalkan lagi strategi tersebut agar kedepannya lebih baik lagi dan dikenal oleh konsumen secara luas. PB. Dua Putra Kalisat Jember terus menjaga kualitas hasil produknya agar diminati oleh para konsumen dan mampu bersaing dengan produk perusahaan lainnya. Perilaku konsumen pada dasarnya merupakan proses memilih, membeli, dan menggunakan produk untuk memenuhi kebutuhan.

Perusahaan PB. Dua Putra di desa Ajung Kecamatan Kalisat Kabuaten Jember ini dalam menjalankan usahanya harus selalu meningkatkan kualitas produknya dengan kualitas terbaik. Guna eksistensi usaha yang ditekuninya sebagai salah satu cara untuk mendapatkan laba guna memenuhi kebutuhannya sendiri dan permintaan para konsumen. Seiring dengan hal itu PB. Dua Putra ini memiliki sebuah strategi untuk menentukan harga yang akan dilakukan terhadap produknya yang akan dijual kepada konsumen. Harga produk atau barang sangat berhubugan dengan produk atau barang itu sendiri. Jika kualitas produk terbaik, tentunya harga akan berada diatas rata - rata. Sebaliknya jika produk berkualitas sedang atau rendah, harganya pun mengikuti. Selain menetapkan harga produknya dari segi kualitas berasnya,

PB. Dua Putra melakukan penetapan strategi harga dari jumlah pembelian. Harga produk tersebut berfungsi untuk memperoleh keuntungan dan untuk proses produksi selanjutnya. Strategi pemasaran bisa terlaksana dengan tepat apabila saluran distribusi produk bisa tercapai dengan lancar dan menjalin komunikasi yang baik antara penyalur distribusi kepada konsumen. Pendistribusian barang juga menggunakan berbagai macam alat transportasi, serta memperluas tempat jaringan distribusi. Fungsi utama distribusi itu sendiri adalah menyebarkan produk kepada konsumen dengan jangkauan yang lebih luas.

PB. Dua Putra Ajung Kalisat Jember merupakan perusahaan yang bergerak dalam bidang usaha penggilingan padi. Pertama berdirinya perusahaan ini diirintis oleh Bapak Budi Yanto pada tahun 1980 dengan nama UD. Dua Putra yang merupakan usaha keluarga berbentuk CV. Lokasi perusahaan ini terletak di desa Ajung - Kecamatan Kalisat dan tempatnya berada di tepi jalan raya Ajung.Perusahaan ini awalnya bergerak dalam bidang penggilingan jagung dengan memakai nama UD. Dua Putra dengan surat izin perusahaan (SIUP) nomor 6551/KP/PDMN/X/1975 yang melayani kebutuhan konsumen disekitar perusahaan dalam skala kecil.

Tahun 1986 kemajuan usaha ini meningkat dengan tambahnya penggilingan untuk padi dan juga melayani setiap penjualan padi dari petani secara langsung. Baru pada 1990 penggilingan jagung sudah tidak dioperasikan. UD. Dua Putra memfokuskan pada penggilingan beras dari berganti nama menjadi Penggilingan Beras (PB). Dua Putra menjadi perusahaan produksi beras siap dikonsumsi yang pemasaran berasnya semakin diminati konsumen di wilayah Jember.Pihak PB. Dua Putra sendiri semakin melakukan perbaikan produknya agar mudah terjangkau oleh konsumen. Serta pemasarannya mulai berorientasi dalam luas wilayah pemasaran tidak hanya di Jember tapi mulai berkembang ke daerah Bondowoso, Situbondo, Lumajang, Banyuwangi dan lain - lain. 


\section{METODE}

Jenis penelitian yang digunakan adalah penelitian deskriptif penelitian deskriptif mempelajari masalah - masalah dalam masyarakat serta tata cara yang berlaku dalam masyarakat dan situasi - situasi tertentu, termasuk tentang hubungan, kegiatan - kegiatan, sikap - sikap, pandangan - pandangan, serta proses - proses yang sedang berlangsung dan pengaruh - pengaruh dari suatu fenomena yang diselidiki. Jadi penelitian deskriptif tidak hanya memaparkan dan memberikan gambaran terhadap fenomena tetapi juga menerangkan hubungan, membuat prediksi, serta mendapatkan makna dan implikasi dari suatu masalah.

Dengan metode deskriptif ini, juga diselidiki kedudukan (status) fenomena atau faktor dan melihat hubungan antara satu faktordengan faktor yang lain. Oleh sebab itu metode deskriptif juga dinamakan studi status. Perspektif waktu yang dijangkau dalam penelitian deskriptif adalah waktu sekarang, atau sekurang kurangnya jangka waktu yang masih terjangkau dalam ingatan responden.

\section{HASIL DAN PEMBAHASAN \\ Hasil Penelitian}

Berdasarkan data yang diperoleh dapat diketahui bahwa, PB. Dua Putra merupakan usaha pabrik beras yang berbadan hukum dan juga memiliki karakteristik tersendiri dari pabrik beras lainnya. Karakteristik yang dimiliki PB. Dua Putra ini berbeda dengan pabrik beras yang lain. PB. Dua Putra menerapkan harga sesuai dengan tingkatan kualitas beras. Seiring berjalannya waktu usaha ini semakin berkembang dan semakin banyak konsumen yang mengkonsumsi bahkan berlangganan beras dengan merk unggulan Cap Dua Anak. Pemilik Wahyu Budianto (83 Tahun) mengembangkan bisnisnya dengan membuka peluang bagi pengangguran khususnya membuka peluang untuk karyawan - karyawan yang sedang mencari pekerjaan dan mengembangkan usaha tersebut yang awalnya hanya bisnis keluarga saja dan sekarang menjadi pabrik cukup yang besar serta menggunakan mesin - mesin penggilingan padi yang baik dan berkualitas sehingga menghasilkan beras yang berkualitas.

PB. Dua Putra merupakan bisnis yang berbasis kemitraan usaha yang melakukan strategi bauran pemasaran dalam meningkatkan keberhasilan usahanya. PB. Dua Putra saat ini adalah pabrik beras yang sedang berkompetitif dengan pabrik beras lainnya. Berdasarkan penelitian yang dilakukan oleh peneliti PB. Dua Putra Jember menggunakan 4 aspek strategi bauran pemasaran yaitu strategi produk, strategi harga, strategi promosi, dan distribusi.

Untuk mengembangkan pangsa pasar dan meraih pangsa pasar maka strategi - strategi yang digunakan antara lain memberikan potongan harga, taktik ini paling banyak digunakan sebagai cara cepat mendapatkan pangsa pasar. Perusahaan berusaha menciptakan posisi biaya yang lebih rendah dibandingkan para pesaing dan meneruskan penghematan biaya tersebut kepada pelanggan dalam bentuk harga yang lebih murah. Harga yang lebih rendah ditambah kualitas yang baik, akan memberikan daya tarik konsumen agar tidak berpaling ke merk lain. Meningkatkan aktivitas promosi, taktik non harga ini bisa diwujudkan dua cara: (1) menaikkan pengeluaran promosi dan iklan secara besar - besaran untuk mengalahkan pemimpin pasar dan (2) mencari pasar yang aktivitas promosi relatif kurang semarak dimasa lalu, kemudian menaikkan anggaran promosi guna merebut pangsa pasar.

Memperluas wilayah pemasaran, dalam mencari wilayah pemasaran baru perusahaan harus betul betul mempertimbangkan untung ruginya. Misalnya perusahaan akan memperluas pasarnya ke daerah Jawa Tengah tetapi di wilayah ini belum ada distributoryang menangani. Maka perusahaan harus memperhitungkan biaya untuk biaya penelitian tentang pasar di daerah tersebut serta biaya lainnya yang akan dikeluarkan misal biaya promosi Memperbaiki kualitas produk, strategi menjual produk berkualitas lebih baik (dalam aspek rasa, lebih higienis, lebih punel, daya tahan, ukuran standar) dibandingkan produk pesaing bila menghasilkan pangsa pasar sepadan. Meningkatkan layanan, peningkatan layanan pra-jual hingga purna jual memberikan nilai tambahan bagi setiap pelanggan. Selain menjadi sumber pemasukan tambahan, faktor layanan bisa menjadi pendorong aktifitas dalam mendukung kemampuan perusahaan merebut pangsa pasar dari pesaing.

Produk utama yang dijual adalah produk jadi berupa beras super dengan berbagai jenis kualitas berdasarkan segmen pasar yaitu keunggulan beras kualitas 1 dinamakan beras super dalam pengemasannya menggunakan nama Dua Anak. Beras ini mempunyai keunggulan dalam rasa dan bentuk fisik beras utuh. Untuk beras kualitas 2 dalam pengemasan menggunakan merk Macan, beras ini meupakan hasil pengkayaan patah 1 yaitu beras yang patah pada salah satu ujungnya dan dicampur beras utuh. Untuk beras kualitas 3 dalam pengemasan menggunakan Merk Nikisae merupakan beras jenis IR - 66 dicampur dengan hasil pengkayaan patah 2.

Produk yang bukan utama meliputi sekam yaitu hasil dari pemisahan beras dengan kulit beras yang nantinya biasa dijual untuk produksi bata. Katul yaitu kulit beras yang halus yang bermanfaat untuk makanan ternak Menir yaitu beras campuran dan sisa ayakan terakhir 
Proses produksi secara garis besar prosdur pemolesan pada bagian produksi adalah perusahaan melakukan pembelian gabah basah, ditimbang untuk selanjutnya dicatat berat dan nomor urutnya kemudian diberikan kartu nomor urut. Gabah basah dijemur dibawah terik matahari selama 3 hari sampai kering hingga kadar airnya menyusut sampai $14 \%$ namun kondisi musim hujan proses pengeringan bisa dilakukan dengan mesin pengering. Proses pengeringan gabah basah berlangsung $2-3$ hari. Gabah yang sudah kering dimasukkan ke gudang untuk didiamkan selama sehari setelah itu baru diproses penggilingan Gabah kering yang sudah memenuhi standar akan dibawa ke ayakan padi dengan menggunakan elevator padi. Padi yang ada isinya dan padi yang kosong kemudian masuk ke mesin giling siap untuk diproses. Dalam mesin akan terjadi pengelupasan gabah dan blower yang ada pada mesin pecah kulit dipisahkan antara beras dan sekam.

Setelah melalui mesin pecah kulit kemudian memasuki separator yaitu mesin yang memisahkan gabah yang sudah pecah kulit dan yang belum pecah kulit. Untuk gabah yang sudah pecah kulitakan turun ke mesin penyaring beras, sedangkan yang belum akan naik ke mesin pemecah gabah. Tahap ini adalah tahap dimana beras yang sudah pecah kulitnya melalui mesin penyaring beras untuk dipisahkan kulitnya Melalui mesin penyaring beras maka beras memasuki mesin poles beras yang berfungsi membersihkan beras dari kotoran kulit gabah. Dari mesin pemoles beras akan memasuki blower katul yaitu mesin yang berfungsi memisahkan beras dengan katulnya. Melalui blower katul beras akan masuk ke elevator untuk dibawa ke mesin pengkilap beras atau masuk ke mesin pemutih beras.

Beras memasuki mesin Qebi yang digunakan untuk memutihkan beras yaitu menghilangkan katul yang masih menempel pada beras melalui pengiupan dengan kecepatan tinggi, sedangkan beras yang memasuki mesin pengkilap beras maka berasnya akan menjadi mengkilap. Beras yang sudah dipoles akan memasuki mesin pengayaan beras. Mesin ini berfungsi memisahkan beras yang utuh dengan beras yang patah. Beras yang patah ini terbagi menjadi beberapa kategori yaitu kategori patah 1 untuk kualitas 1l, patah 2 untuk kualitas 1ll, patah 3,4,5 untuk beras campuran dan sisa ayakan terakhir disebut menir. Sesudah melewati ayakan beras maka akan ditimbang sesuai yang ditetapkan yaitu $5 \mathrm{~kg}, 10 \mathrm{~kg}, 25 \mathrm{~kg}, 50 \mathrm{~kg}$. Proses terahkir setelah melalui penimbangan beras di kemas berdasarkan merk yang ada.

Distribusi yang dilakukan oleh PB Dua Putra menggunakan dua saluran langsung dan tidak langsung. Saluran distribusi langsung yang dijalankan yaitu pimpinan perusahaan sudah menyediakan stok beras dengan perbedaan lokasi dengan pabrik beras yaitu pada garasi rumah yang ukurannya cukup luas dimana bisa menampung cukup banyak sak beras. Jadi konsumen dan tengkulak dengan mudah men-stok beras mereka secara langsung. Sedangkan distribusi secara tidak langsung melalui mobil - mobil box dan truk angkut yang sudah disediakan oleh perusahaan itu sendiri untuk menjangkau distributor/ agen dengan cakupan pemasaran yang lebih luas. Seperti yang dijelaskan kutipan wawancara berikut:

"pengiriman sudah meluas di daerah Jeber mbak, dan kota - kota besar lainnya seperti sudah sampai menjangkau Surabaya, Situbondo dan sebagainyabahkan sampai ke luar pulau tetapi tidak banyak. ”(E, $40^{\text {th }}$ )

Jangkauan pemasaran PB. Dua Putra cukup meluas hingga sampai ke luar pulau menggunakan menggunakan alat transportasi berat seperti container dengan muatan bisa mencapai 23 ton seperti yang dijelaskan oleh kutipan wawancara berikut:

"Kalau dalam kota Jember, hamper seluruh wilayah terjangkau terutama Kalisat. Kalau luar kota bahkan luar pulau sampai ke Sulawesi, Kalimantan, Papua, dan Timika. Biasanya lewat jasa transportasi, kalau luar pulau pakai container dengan muatan 23 ton. " $\left(H, 49^{\text {th }}\right)$

Setelah peneliti melakukan penelitian melalui observasi secara langsung dan wawancara dengan beberapa informan dan melakukan studi pustaka dari beberapa literatur terkait dengan promosi dapat diketahui bahwa PB. Dua Putra khususnya memiliki acuan pokok dalam menentukan langkah - langkah aktivitas promosi produk beras Cap Dua Anak, Cap Macan, dan Nikisae. Acuan pokok tersebut adalah selalu menjaga kualitas beras dan desain kemasan sederhana yang jarang diperbarui agar mudah untuk diingat masyarakat.

"Kami selalu menjaga kualitas beras mbak,sederhananya seperti itu. Desain kemasan yang kami buat itu sederhana saja mbak, tetapi yang sekiranya mudah diingat orang banyak. Tidak mbak, sudah lama tidak diperbarui." (W, $\left.81^{\text {th }}\right)$

Dari pendapat tersebut dapat diketahui bahwa PB. Dua Putra mengutamakan menjaga kualitas beras agar beras yang diproduksi tetap punel dan hamper tidak pernah mengganti kemasan produk agar lebih mudah diingat oleh masyarakat dari berbagai generasi. Hal ini dikarenakan banyaknya pesain penggilingan beras dengan produk beras mereka yang berbagai macam merk dan kualitas beras yang cukup baik pula.

Pada awalnya PB. Dua anak sudah mengeluarkan produk beras dengan kualitas beras yang baik sebelum perusahaan -peusahaan pesaing memproduksi beras dengan kualitas yang sama. Direktur perusahaan sudah memulai usahanya semenjak tahun 1980 sehingga masyarakat sekitar khususnya kawasan Jember sulit untuk berpaling pada merk beras yang lain. Respon masyarakat yang cukup bagus menjadi acuan bagi PB. Dua Putra untuk tetap mempertahankan kualitas beras mereka. 
"Cara memperkenalkan produk terutama ayah itu membuat beras bagus terlebih dahulu sebelum didahulukan oleh orang lain. Dan akhirnya masyarakat mengenal dengan beras kualitas bagus tersebut dan enak sehingga masyarakat tidak mudah berpaling dari merk beras kami terutama Du' Anak.” (E, $\left.40^{\text {th }}\right)$

Dalam menentukan harga beras PB. Dua Putra tidak serta merta mempertimbangkan harga beras terkait dengan kualitas beras saja tetapi kurang lebih ada campur tangan pemerintah untuk menstabilkan harga beras di pasaran. Secara operasional masalah ini adalah upaya pemerintah untuk mempengaruhi harga beras karena beras menjadi kebutuhan pokok masyarakat Indonesia maka sangat dibutuhkan campur tangan pemeritah dalam hal ini khususnya dengan kebijakan langsung dan tidak langsung.

"Untuk penentuan harga sendiri itu melalui harga pasar pada umumnya jadi tidak bisa menentukan sendiri. Misal harga di pasar sedang turun ya turun misal sedang naik ya naik.” (H, 49 $\left.9^{\text {th }}\right)$

Akan tetapi disamping itu PB. Dua Putra juga mempunyai standar patokan harga tersendiri. Dari patokan harga tersebut PB. Dua Putra menggolongkan produk beras mereka sesuai dengan kualitas beras yaitu premium dan medium. Premium untuk beras dengan merk Cap Du' Anak dengan kualitas terbaik, sdangkan medium untuk beras dengan merk Cap Macan dan Nikisae dengan kualitas beras dibawah Cap Du' Anak.

Rata - rata keuntungan penggilingan beras mulai dari gabah hingga menjadi beras yaitu berkisar 300 500 rupiah karena tidak semua selep memberi beras dari gabah. Data berikut ini merupakan daftar harga terakhir pada bulan Januari 2019 yang dikeluarkan oleh PB. Dua Putra Kalisat Jember

\section{Pembahasan}

Berdasarkan hasil penelitian yang dilakukan, dapat diketahui bahwa merk beras yang paling dikenal atau paling banyak dikonsumsi oleh masyarakat Jember khususnya warga Kalisat yaitu Beras Cap Dua Anak dan Beras Cap Macan. Hal ini tidak terlepas dari adanya strategi pemasaran yang dilakukan oleh pihak perusahaan PB. Dua Putra di Desa Ajung Kecamatan Kalisat Kabupaten Jember. Strategi bauran pemasaran juga memiliki unsur harga yang mempunyai peran penting terhadap daya tarik dan kepuasan konsumen. Harga yang terjangkau dan produk yang mempunyai kualitas juga menjadi daya tarik konsumen terhadap perusahaan. Penentuan harga yang diterapkan oleh PB. Dua Putra Desa Ajung Kecamatan Kalisat Jember kepada para konsumen mengacu kepada kualitas beras dan menyesuaikan harga di pasaran.

PB. Dua Putra perusahaan penggiling padi yang cukup besar menggunakan strategi produk dengan cara mengeluarkan 3 merk unggulan dengan kualitas yang berbeda. Merk beras terbagi menjadi 3 macam tingkatan kualitas yaitu, kualitas premium dengan merk Cap Dua Anak, kualitas medium dengan merk Cap Macan dan Nikisae. Ketiganya masuk dalam kategori kualitas beras unggulan hanya yang membedakan adalah proses penggilingannnya. Sama - sama merupakan beras punel tetapi beras Cap Dua Anak paling punel diantara dua merk tersebut. Supaya menghasilkan beras yang punel perusahaan harus bisa gabah mana yang kaku dan yang tidak agar kualitas beras tetap terjaga dan kualitas mesin penggilingannya pun harus dengan kualitas yang terbaik. Desain kemasan pada karung beras juga terbilang cukup sederhana dan tidak diperbarui agar mudah diingat oleh kebanyakan masyarakat.

Saluran distribusi yang digunakan perusahaan yaitu saluran distribusi secara langsung dan tidak langsung. Dimana PB. Dua Putra terdapat dua titik penjualan, di pabrik itu sendiri dan di garasi rumah pemilik dengan lokasi titik yang berbeda. Saluran distribusi secara langsung yang digunakan oleh PB. Dua Putra yaitu distribusi secara langsung dengan konsumen - konsumen atau agen yang sedang kulak memalui istri dari si pemilik yang berjaga di garasi pasokan beras. Sedangkan saluran distribusi secara tidak langsung bertitik pada pabrik itu sendiri dimana disana telah tersedia cukup banyak mobil box siap antardan tenunya stok beras di pabrik jauh lebih banyak. Beras yang dihasilkan per harinya bisa sampai 15 - 20 ton.

Proses produksi dari gabah sehingga menjadi beras yang punel berawal dari pembelian padi melalui petani. Pembelian gabah pada saat musim kemarau bisa lebih rendah $10 \%$ dari biasanya dan pada saat musim penghujan bisa lebih tinggi 10\% - 20\% dari harga biasanya, belum dipotong kadar air, belum dengan musibah, dan penyakit tanaman pada umumnya. Terdapat dua macam pengeringan yaitu jemur dan oven. Penjemuran biasanya dilakukan di halaman pabrik yang cukup luas. Gabah dijemur di tempat tersebut dalam rentan waktu 1 - 2 hari atau 3 - 5 hari apabila terjadi hujan. Sedangkan pengeringan padi melalui oven rentan waktu lebih sebentar yaitu 6-12 jam dan didiamkan selama 1 malam agar hasilnya lebih bagus. Gabah digiling dijadikan beras harus melewati proses pecah kulit dan menghasilkan sekam dan beras hitam. Proses selanjutnya beras tersebut dipoles sehingga menjadi lebih mengkilat.

Perbedaan kualitas beras antara ketiga merk beras PB. Dua Putra tersebut bisa dilihat dari pross penggilingannya. Beras dengan kualitas premium dengan merk beras cap dua anak, dari proses poles melewati proses ayakan atau filter karena masih terdapat beras yang patah atau hancur. Pada saat keluar menir, masuk ke dalam mesin kebi dan beras yang patah tadi tidak turut masuk atau disisihkan. Beras dengan kualitas medium dimana beras dengan merk cap macan ini tidak di edarkan ke luar kota. Proses penggilingannya pun masuk ke dalam mesin kebi tetapi tidak dengan diayak. Yang terakhir beras dengan merk Nikisae, pecahan beras dicampur 
dengan beras murah atau beras kaku dan tanpa melalui proses kebi. Sesuai dengan hasil wawancara bahwa hamper semua selep harus membeli gabah kepada petani.

Pemasaran beras PB. Dua Putra mencakup dalam kota, luar kota bahkan sampai luar pulau seperti Sulawesi, Kalimantan, Papua dan Timika menggunakan kapal laut. Pengiriman barang mereka tergolong tepat waktu dan maksimal batas pengiriman ke luar pulau kurang dari sminggu. Kemasan produk yang diedarkan keluar kota kemasan tertentu yaitu kemasan $5 \mathrm{~kg}, 10 \mathrm{~kg}$ dan $25 \mathrm{~kg}$ melalui jasa transportasi. Jika stok beras dalam kota tidak mencukupi maka perusahaan akan stok beras ke luar kota. Untuk promosi awal, PB. Dua Putra menggunakan trik harga murah dan terdapat kupon hadiah langsung didalam kemasan sak beras. Kemudian kupon tersebut diundi di area pabrik beras tersebut. Selain melalui radio dan kupon undian, PB. Dua Putra mempromosikan produknya dengan banner dan pamflet pada mobil - mobil box distribusi.

\section{PENUTUP}

PB. Dua Putra Ajung Kalisat Jember merupakan perusahaan produksi beras yang berbadan hukum dan perusahaan yang memiliki strategi tersendiri untuk menjual produknya kepada konsumen. PB. Dua Putra Ajung Kalisat Jember menerapkan strategi bauran pemasaran yang meliputi strategi produk, strategi harga, strategi promosi, dan strategi distribusi.

Strategi produk dalam PB. Dua Putra Ajung Kalisat Jember yaitu menjual produknya berupa beras dengan kualitas yang berbeda. Strategi harga merupakan penetapan harga dengan mempertimbangkan kualitas beras yang diterapkan PB. Dua Putra Ajung Kalisat Jember, strategi promosi dilakukan dengan melalui internet, brosur, banner dan juga pamflet yang bertujuan menarik keminatan konsumen untuk membeli produknya, strategi distribusi PB. Dua Putra Ajung Kalisat mendistribusikan beras menggunakan saluran distribusi langsung dan saluran distribusi tidak langsung.

Strategi bauran pemasaran yang dilakukan memiliki hubungan timbal balik yang dirasakan suatu usaha, hal ini terbukti dengan banyaknya pelanggan yang begitu percaya dengan jasa yang ditawarkan oleh PB. Dua Putra Ajung Kalisat Jember. Kepuasan konsumen menjadi tolak ukur yang utama yang menunjukkan keunggulan PB. Dua Putra Ajung Kalisat Jember yang menjual produknya dengan perusahaan penjual beras lainnya yang sejenis.

\section{DAFTAR PUSTAKA}

Buku

Ariffudin, 2009. Metode Penelitian Kualitatif. Bandung: CV. Pustaka Setia

Furchan, A., 1992. Pengantar Metode Penelitian Kualitatif. Surabaya: Usaha Nasional

Gitosudarmo, I. 2001. Manajemen Strategis. Yogyakarta: PBFE

Steiner, A. Miner John B. 1988, Kebijakan dan Strategi Manajemen. Jakarta: Erlangga.

Tjiptono, F. Chandra Gregorius, dan Adriana Dedi. 2008. Pemasaran Strategik. Yogyakarta: Penerbit Andi.

Nazir, M. 2013. Metode Penelitian. Bogor: Ghalia Indonesia

Moleong, J. 2012. Metode Penelitian Kualitatif. Bandung: PT. RemajaRosdakarya.

Kerin, R. A.Peterson Robert. 2007. Pemasaran Strategis. Jakarta Barat: PT. Index.

Kothler, P. Amstrong, Gary. 2008. Manajemen Pemasaran. Jakarta: Erlangga

Assauri, S. 2007. Manajemen Pemasaran. Jakarta: PT. Raja Grafindo Persada

Lovelock, C. 2010. Services Marketing. Jakarta: Erlangga

Peter, J.P. 2014. Perilaku Konsumen da Strategi Pemasaran. Jakarta: ISBN

Brannen, J. 2002. Metode Penelitian Kualitatif dan Kuantitatif. Yogyakarta: Pustaka Pelajar Offset 